\title{
Determinants of Bank Profitability in Nigeria: Using Camel Rating Model (2001 - 2010)
}

\author{
${ }^{1}$ Echekoba, F.N., ${ }^{2}$ Egbunike, Chinedu Francis, ${ }^{3}$ Ezu Gideon Kasie \\ ${ }^{I}$ Department of Banking \& Finance, Faculty of Management Sciences Nnamdi Azikiwe University, P.M.B. 5025, \\ Awka, Nigeria \\ ${ }^{2}$ Department of Accountancy, Faculty of Management Sciences Nnamdi Azikiwe University, P.M.B. 5025, Awka, \\ Nigeria \\ ${ }^{3}$ Banking and Finance Department, Faculty of Management Sciences ${ }^{3}$ Nnamdi Azikiwe University, P.M.B. 5025, \\ Awka, Nigeria
}

\begin{abstract}
Sound financial environment of the banking industry is the guarantee not only to her depositors but equally significant to the shareholders, employees and the whole economy as well. In line to this, efforts have been made from time to time to measure the performance of banks in the country. A number of factors are used in the measurement of banks performance in a typical developing economy and among these is profitability. This study was based on the determinants of banks profitability in Nigeria: using CAMEL model. The objective of the study was to determine the impact of CAMEL on the profitability of Nigerian banks. The data of the commercial banks in Nigeria were obtained for the period of 2001 to 2010. The model was estimated using ordinary least square method and the Statistical Package for Social Sciences (SPSS) 19. The findings based on the analysis elucidate that liquidity has a significant impact on banks profitability while capital adequacy, assets quality, management efficiency, earning did not. It was then recommended that banks should make sure that they maintain a reasonable liquidity position at all times to meet up regular financial obligations thereby maintaining depositors' confidence in the industry and increase profitability.
\end{abstract}

Keyword: Bank, Profitability, Capital Adequacy, Camel, And Liquidity

\section{Introduction}

The financial sector is the backbone of the economy of a country. It works as a facilitator for achieving sustained economic growth through providing efficient monetary intermediation. A strong financial system promotes investment by financing productive business opportunities, mobilizing savings, efficiently allocating resources and makes easy the trade of goods and services. Banks serve the vital intermediary role in a market oriented economy and have been seen as the key to investment and growth. Commercial banks play a crucial role in the nation's economy, by using various financial instruments to obtain surplus funds from those that forgo current consumption for the future. They also make same funds available to the deficit spending unit (borrowers) for investment purposes. In this way, they make available the much needed investible funds required for investment as well as for the development of the nation's economy. A profitable and sound banking sector is at a better point to endure adverse upsets and adds performance in the financial system and performance evaluation through the determination of profitability is one of the important approaches for enterprises to give incentive and restraint to their operations and it is an important channel for enterprise stakeholders to get the performance information. The performance through profitability evaluation of banks is usually related to how well the bank can use its assets, shareholders' equities and liabilities, revenue and expenses. The performance evaluation of banks is important for all parties including depositors, investors, bank managers and regulators. One of the ways to determine the performance of banks is through the determination of its profits. The evaluation of banks performance usually employs the financial ratio method which provides a simple description about banks financial performance in comparison with previous periods and helps to improve its performance of management. Financial ratios based on CAMEL framework are related to capital, assets, management, earnings and liquidity considerations. These ratios include return on assets (ROA), capital adequacy ratio (CAR), non-performing loan ratio (NPL), credit to deposit ratio (CDR), yield to earnings ratio (YEA) and liquidity ratio (LR).

\section{Statement Of The Problem}

The stream of bank failures experienced in the USA during the great depression of the 1940s prompted considerable attention to bank performance and the attention has grown ever since then. The recent global financial crises of 2007 - 2008 also demonstrated the importance of bank performance both in national and international economics and the need to keep it under surveillance at all times. According to Athanasoglou et al (2008), banks are typically the major source of finance for the majority of firms and are usually the main 
depository of economic savings. There are many aspects of the performance of banks that can be analyzed and this study focuses on the profitability performance determination using the CAMEL model.

\section{Objectives Of The Study}

The objectives of the study are:

1. To determine the impact of capital adequacy on the profitability of Nigerian banks.

2. To determine the impact of asset quality on the profitability of Nigerian banks.

3. To determine the impact of management efficiency on profitability of Nigerian banks

4. To determine the impact of earnings on the profitability of Nigerian banks.

5. To determine the impact of liquidity on the profitability of Nigerian banks.

\section{Statement Of Hypotheses}

Ho: Capital adequacy does not have any significant impact on the profitability of banks in Nigeria.

Ho: Asset quality does not have any significant impact on the profitability of banks in Nigeria.

Ho: Management efficiency does not have any significant impact on the profitability of banks in Nigeria.

Ho: Earnings does not have any significant impact on the profitability of banks in Nigeria.

Ho: Liquidity does not have any significant impact on the profitability of banks in Nigeria.

\section{Review Of Related Literature}

In the process of continuous evaluation of the bank's financial performance both in public sector and private sector, the academicians, scholars and administrators have made several studies on the CAMEL model but in different perspectives and in different periods.

Cole et al. (1995) conducted a study on "A CAMEL Ratings' Shelf Life" and their findings suggest that, if a bank has not been examined for more than two quarters, off-site monitoring systems usually provide a more accurate indication of survivability than its CAMEL rating.

Godlewski (2003) tested the validity of the CAMEL rating typology for bank's default modelisation in emerging markets. He focused explicitly on using a logical model applied to a database of defaulted banks in emerging markets.

Said and Saucier (2003) examined the liquidity, solvency and efficiency of Japanese Banks using CAMEL rating methodology, for a representative sample of Japanese banks for the period 1993-1999, they evaluated capital adequacy, assets and management quality, earnings ability and liquidity position.

Prasuna (2003) analyzed the performance of Indian banks by adopting the CAMEL Model. The performance of 65 banks was studied for the period 2003-04. The author concluded that the competition was tough and consumers benefited from better services quality, innovative products and better bargains.

Bhayani (2006) analyzed the performance of new private sector banks through the help of the CAMEL model. Four leading private sector banks - Industrial Credit \& Investment Corporation of India, Housing Development Finance Corporation, Unit Trust of India and Industrial Development Bank of India - had been taken as a sample.

Gupta and Kaur (2008) conducted the study with the main objective to assess the performance of Indian Private Sector Banks on the basis of Camel Model and gave rating to top five and bottom five banks. They ranked 20 old and 10 new private sector banks on the basis of CAMEL model. They considered the financial data for the period of five years i.e., from 2003-07.

\section{The Concept Of Camel}

CAMEL is the acronym for the factors that form the basis for bank rating system. These factors are capital adequacy, asset quality, management efficiency, earnings and liquidity. Under this rating system, banks are rated in relation to the quality of these factors. The strength of these factors would determine the overall strength of the bank. The quality and strength of these factors enables the regulatory authorities to focus on the banks that are not doing well and to pay special attention to them. The regulatory authorities not only study the financial statements of the banks, but also carry out on-site inspection and thereafter, rate the bank. The rating system is based on a scale of one to five (1 -5) with one (1) being the highest score and five (5) the lowest. Banks scoring one (1) would be considered as among the top bracket in regard to their financial soundness, and those scoring five (5) would be seen to be at the bottom of the ladder.

\section{Empirical Framework}

The trend of banking is changing rapidly. Competition is getting stiffer and, therefore, banks need to enhance their competitiveness and efficiency by improving performance. These significance changes are also occurring in the banking sector of developing economics like Nigeria. These changes have increased the importance of performance analysis of modern banks. Normally, the financial performance of commercial banks 
and other financial institutions has been measured using a combination of financial ratio analysis, benchmarking, measuring performance against budget or a mix of these methodologies. Financial analysis using financial ratios is used to determine the different areas of bank performance such as profitability, asset quality and solvency. According to Abdulkadir (2007), financial analysis can be described as the process of identifying the financial strengths and weaknesses of a firm by establishing relationship between the items on balance sheet and profit and loss account. Also, Abdulraheem (2004) reported that a good means of measuring the performance of a bank and other business organizations is the financial ratio, which shows the relationship between data in the financial statement. H0 and Zhu (2004) have reported that the evaluation of a company's performance has been focusing the operational effectiveness and efficiency, which might influence the company's survival directly.

Bakar and Tahir (2009) in their paper used multiple linear regression techniques and simulated neural network techniques for predicting bank performance. Return on Asset (ROA) was used as dependent variable of bank performance and seven variables including liquidity, credit risk, cost to income ratio, size and concentration ratio were used as independent variables. They concluded that neural network method out performs the multiple linear regression method however, it need clarification on the factor used and they noted that multiple linear regression can be used as a simple tool to study the linear relationship between dependent and independent variables. Also, Neceur (2003) using a sample of ten Tunisian banks from 1980 to 2000 and a panel linear regression model, reported a strong positive impact of capitalization of ROA.

Another

yardstick for measuring performance in the banking industry is the CAMEL approach which is equally used by monitoring authorities to asses the level of performance of banks before making any pronouncement on their soundness, solvency and liquidity position. There are number of studies which examined the bank performance using CAMEL framework which is the latest and most widely used model of financial analysis.

Elyor (2009) have used CAMEL model to examine factors affecting bank profitability with success. The central Bank of Nigeria also used the CAMEL framework for performance evaluation of the banks.

Jha and Hui (2012) also used CAMEL model to compare the financial performance of commercial banks in Nepal by identifying the determinants of performance. They used regression models to estimate the impact of capital adequacy ratio, non-performing loan ratio, interest expenses to total loan, net interest margin and credit to deposit ratio on the financial profitability namely Return on Assets (ROA) and Return on Equity (ROE). (ROA) was significantly influenced by capital adequacy ratio, interest expenses to total loan and net interest margin, while capital adequacy ratio had considerable effect on return on equity. The result of their findings revealed that return on assets (ROA) was significantly influenced by capital adequacy ratio, interest expenses to total loan and net interest margin, while capital adequacy ratio had considerable effect on return on equity.

\section{Capital Adequacy And Banks Profitability}

Capital adequacy refers to the sufficiency of the amount of equity to absorb any shocks that the bank may experience Nwankwo (1991).

The capital structure of banks is highly regulated. This is because capital plays a crucial role in reducing the number of bank failures and looses to the stakeholders . According to Hardy and Bonaccorsi di Patti (2001)Nwankwo, (1991), capital adequacy is a widely acknowledged key factor in bank performance measurement and evaluation. It is the first of the five CAMEL factors recognized and adopted by the Basel system of bank performance assessment of the Bank for International Settlement (BIS). The capital adequacy measurement using capital adequacy ratio was adopted in the Nigeria banking system in 1990. It is the ratio of the capital of a bank (i. e. Tier 1 and Tier 2 capital) in relation to its weighted assets. The banks must meet the minimum requirements stipulated by the bank monitoring and supervising authority which is the Central Bank of Nigeria (CBN) in the case of Nigeria. Although there is general agreement that statutory capital requirements are necessary to reduce moral hazards, Beckmann (2007) argue that high capital lead to low profits since banks with a high capital ratio are risk-averse, they ignore potential (risky) investment opportunities and as a result, investors demand a lower return on their capital in exchange for lower risk.

\section{Asset Quality And Profitability Of Banks}

The quality of assets held by a bank depends on the exposure to specific risks, trends in nonperforming loans, and the health and profitability of bank borrowers. Poor asset quality and low levels of liquidity are the two major causes of bank failures. Many financial institutions that collapse are due to high rate of non-performing loans (NPLs) and extensive insider lending. Credit risk is one of the factors that affect the health of banks. The extent of the credit risk depends on the quality of assets held by bank. The quality of assts held by a bank depends on exposure to specific risks, trends in non-performing loans, and the health profitability of bank borrowers. 


\section{Management Efficiency And Profitability Of Banks}

Management quality or efficiency plays a big role in determining the future of the bank. The management has an overview of a bank's operations, manages the quality of loans and has to ensure that the bank is profitable.

The performance of management capacity is usually qualitative and can be understood through the subjective evaluation of management systems, organization culture, and control mechanisms and so on. However, the capacity of the management of a bank can also be gauged with the help of certain ratios of off-site evaluation of a bank in the capacity of the management to deploy its resources aggressively to maximize the income, utilize the facilities in the bank productively and reduce costs, etc. According to Sangmi and Nazir (2010), management efficiency can be evaluated with reference to expenditure to income ratio, credit to deposit ratio, Asset utilization ratio, diversification ratio, earnings per employee ratio and expenditure per employee ratio.

\section{Earnings And Banks Profitability}

The earnings of a bank refer to the profit made by it. Profit is the difference between income and expenditure. The major source of income for banks are interest earned on loans and other incomes derived from general banking activities while expenditure of banks may relate among other things, to salaries, wages, rents, administrative overheads, taxes, etc. It is the surplus that remains after taking care of all expanses that is known as net profit. A wealthy bank should be able to generate decent profits regulatory and keep itself as well as its investors, in good health because the ability of a bank to support her present and future operations depends on the quality of its earnings and profitability.

\section{Liquidity And Banks Profitability}

Another important decision that the managers of commercial banks take refers to the liquidity management. Liquidity is simply the ease with which assets of banks can be encashed in times of need or its fair value. It is that quality of an asset that enables a bank to respond to any financial situation requiring urgent infusion of money. Liquidity is required to meet regular financial obligations of the bank especially without dipping into its reserves. When banks hold high liquidity, they do so at the opportunity cost of some investment which could generate high returns. The trade-offs that generally exist between return and liquidity risk are demonstrated by observing that a shift from short-term securities to long-term securities or loans raises a bank's return but also increases its liquidity risks and the inverse in is true. Thus a high liquidity ratio indicates a less risky and less profitable bank.

\section{Methodology}

The objective of this study is to determine the effect of CAMEL on the profitability of banks in Nigeria. The study focus on commercial banks in Nigeria. The data are obtained from the Central Bank of Nigeria $(\mathrm{CBN})$ annual reports and statement of accounts, CBN statistical bulletin, Nigeria Deposit Insurance Corporation (NDIC) annual report and statement of accounts. Time series data is used and the period covered in the study is 2001 to 2010 . The model in this study is estimated by Ordinary Least Square (OLS) method using the Statistical Package for Social Sciences (SPSS) 19.

The profitability ratio return on asset (ROA) is assumed as the dependent variable while capital adequacy ratio (CAR), Non performing loan ratio (NPL), Credit -to-Deposit ratio (CDR), Earnings ratio (YEA) and liquidity ratio (LR) are assumed as the independent variables. These ratios represent CAMEL as the independent variables and ROA as the dependent variable.

\section{Model Specification}

The model that is used in this study is adopted from the empirical study of Baker and Tahir (2009), Neceur (2003), Elyor (2009), Jha and Hui (2012).

The equation and econometric model is presented thus:

$\mathrm{ROA}=\mathrm{f}(\mathrm{CAMEL})$

\begin{tabular}{|c|c|c|c|}
\hline \multirow[t]{8}{*}{$\begin{array}{l}\mathrm{ROA}=\mathrm{B}_{\mathrm{O}}+ \\
\text { Where } \mathrm{X}_{1}\end{array}$} & $\begin{array}{c}X_{1}- \\
=\end{array}$ & $\mathrm{X}_{2}+$ & $\begin{array}{l}3+\mathrm{B}_{4} \mathrm{X}_{4}+\mathrm{B}_{5} \mathrm{X}_{5}+\varepsilon \ldots \ldots \ldots(2) \\
\text { apital Adequacy Ratio) }\end{array}$ \\
\hline & $\mathrm{X}_{2}$ & $=$ & NPL (Non-performing Loan Ratio) \\
\hline & $\mathrm{X}_{3}$ & $=$ & CDR (Credit-to-Deposit Ratio) \\
\hline & $\mathrm{X}_{4}$ & $=$ & YEA (Yield on Earnings Assets) \\
\hline & $\mathrm{X}_{5}$ & $=$ & LR (Liquidity Ratio) \\
\hline & $\varepsilon$ & $=$ & Stochastic Error term. \\
\hline & Bo & $=$ & Constant \\
\hline & B & $=$ & Coefficient of variables \\
\hline
\end{tabular}




\section{Interpretation Of Result}

Table 1: Diagnosis Test Of The Model

\begin{tabular}{|c|c|c|}
\hline Variable & Value & $\mathbf{P}$ - Value \\
\hline $\mathrm{R}^{2}$ & 0.884 & \\
\hline $\mathrm{DW}$ & 2.839 & 0.015 \\
\hline $\mathrm{F}$ & 9.484 & \\
\hline
\end{tabular}

$\mathbf{R}^{2}$ - In the regression result, the $\mathrm{R}^{2}$ obtained is 0.884 , this implies that $88.4 \%$ of ROA is explained by the independent variables. This indicates a good fit of the regression line.

DW - The Durbin Watson as shown in the regression analysis is 2.839 which shows that there in the presence of autocorrelation.

F statistics calculated is 9.484 while its probability value is 0.015 which is less than 0.05 , we accept that the regression equation is statistically significant.

Table 2: Showing The Coefficients, T- Value And Probability Significance Value

\begin{tabular}{|c|c|c|c|c|c|}
\hline Model & & Coefficients & Std. Error & T - Value & Prob. Sig \\
\hline Constant & $\mathrm{B}_{0}$ & -87.090 & 29.487 & -2.953 & 0.032 \\
\hline $\mathrm{C}$ & $\mathrm{B}_{1}$ & -31.434 & 36.810 & -0.854 & 0.432 \\
\hline $\mathrm{A}$ & $\mathrm{B}_{2}$ & -1.108 & 0.483 & -2.293 & 0.070 \\
\hline $\mathrm{M}$ & $\mathrm{B}_{3}$ & -1.214 & 0.492 & -2.174 & 0.085 \\
\hline $\mathrm{E}$ & $\mathrm{B}_{4}$ & 0.663 & 0.532 & 1.247 & 0.268 \\
\hline $\mathrm{L}$ & $\mathrm{B}_{5}$ & 2.088 & 0.505 & 4.135 & 0.009 \\
\hline
\end{tabular}

The constant value of 87.090 implies that without the predictors used, the ROA will decrease by 87.090 units and a unit increase in $\mathrm{C}$ will lead to a 31.434 decrease in ROA. A unit increase in A will lead to a 1.108 decrease in ROA. A unit increase in $\mathrm{M}$ will lead to a 1.214 decrease in ROA. Also, a unit increase in $\mathrm{E}$ will lead to a 0.663 increase in ROA. Finally, a unit increase in L will lead to a 2.088 increase in ROA.

\section{Test Of Hypothesis}

$\begin{array}{lllllll}\mathrm{C} & - & 0.432 & > & 0.05 & & \text { Accept } \mathrm{H}_{0} \\ \mathrm{~A} & - & 0.070 & & > & 0.05 & \text { Accept } \mathrm{H}_{0} \\ \mathrm{M} & - & 0.085 & > & 0.05 & & \text { Accept } \mathrm{H}_{0} \\ \mathrm{E} & - & 0.263 & & > & 0.05 & \text { Accept } \mathrm{H}_{0} \\ \mathrm{~L} & - & 0.009 & & < & 0.05 & \text { Accept } \mathrm{H}_{1}\end{array}$

From the test of hypothesis, it can be discovered that the probability significance of $\mathrm{C}(0.432)$, A (0.070), M (0.085), E (0.263) which are the probability significance of the ratios representing $\mathrm{C}, \mathrm{A}, \mathrm{M}$ and $\mathrm{E}$ are greater than 0.005 while that of LR $(0.009)$ is less than 0.005 representing L.

\section{Conclusion And Recommendations}

So, the study using CAMEL to determine the profitability of banks in Nigeria showed that liquidity has a significant impact on the profitability of banks in Nigeria while capital adequacy, asset quality, management efficiency, earnings have insignificant impact on the profitability of banks in Nigeria. Based on the findings, it is recommended that banks should keep more of liquid assets that can be encashed easily in order to meet regular financial obligations and then, keep investors and customers' confidence in the system in order to increase profitability.

\section{References}

[1]. Abdulkadir, R. I. (2007): "Financial Statement Analysis As a Measure of Performance; A Case Study of Chevron Oil Producing, Nigeria". Being a Seminar Paper presented at the Department of Accounting, Bayero University, Kano.

[2]. Abdulraheem, A. (2004): "Ratio Analysis As a Measure of Performance in the Banking Industry: A Case Study of Selected Banks in Advances in Management." A Publication of the Department Business Administration, University of Ilorin, Nigeria, 130 - 140.

[3]. Abdulraheem, A. Yahaya, K. Ahu, O, (2011): "Determinants of Performance: A Cross-generational Analysis of Nigerian Banks". European Journal of Social Sciences, 24(4).

[4]. Bakar N. and Tahir I M (2009): "Applying Multiple Linear regression and Neural Network to Predict Bank performance". International Business Res., 2 (4): 176 - 183

[5]. Bhayani, S. (2006). Performance of the New Indian Private Sector Banks: A Comparative Study. Journal of Management Research, Vol. 5, No.11, pp. 53-70.

[6]. Central Bank of Nigeria (2010): "Statistical Bulletins" www.centralbank.org.

[7]. Central Bank of Nigeria (2010): "Banking Supervision Annual Report". www.centralbank.org.

[8]. Cole, Rebel A. and Gunther, Jeffery, (1995). A CAMEL Rating's Shelf Life. Available at SSRN: http://ssrn.com/abstract=1293504

[9]. Derviz, A., \& Podpiera, J. (2008). Predicting Bank CAMEL and S\&P Ratings: The Case of the Czech Republic. Emerging Markets, Finance \& Trade, 44(1), 117. Retrieved April 13, 2010, from ABI/INFORM Global. (Document ID: 1454963901). 
[10]. Elyor S. (2009): "Factors Affecting the Performance of Foreign Banks in Malaysia". Masters Degree Thesis, University of Utara, Malaysia.

[11]. Godlewski, C. (2003). Bank's Default Modelisation: An Application to Banks from Emerging Market Economies. Journal of Social Science Research Network, Vol.4, No.3, pp. 150-155.

[12]. Gupta, R. (2008). A CAMEL Model Analysis of Private Sector Banks in India. Journal of Gyan Management, Vol.2, No.1, pp. 3 -8.

[13]. Hardy, D. C. and Bonaccorsi di Patti, E. (2001): "Bank Reform and Bank Efficiency in Pakistan". IMF Working Paper WP/101/138, Middle Eastern Department.

[14]. Ho C, and Zhu D. (2004): "Performance Measurement of Taiwan Commercial Banks". International Journal of Production, Performances and Management, 53(5): 425 - 434.

[15]. Jha and Hui (2012): "A Comparison of Financial performance of Commercial banks: A case study of Nepal”. African Journal of Business management, 6(25). $7601-7611$

[16]. Nigerian Deposit Insurance Corporation (2010): “Annual Reports.

[17]. Nwankwo, G. O; (1991), Bank management: principles Malthouseand practice press ltd Lagos

[18]. Neceur, S. (2003): "The Determinants of the Tunisian Banking Industry profitability: Panel Evidence".

[19]. www.mafhoum.com/press6/174E11.

[20]. Nwude, E. Chuke (2012): "A Survey of Bank Profitability and Market Value". International Journal of Advanced Scientific and Technical Research, 2 (5).

[21]. Okafor, F. O. (2011): "50 Years of Banking Sector Reforms in Nigeria (1960 - 2010): Past lessons - Future Imperatives". Ezu Books Ltd, Enugu.

[22]. Olweny, T., Shipho, T. M. (2011): "Effects of Banking Sectoral Factors on the Profitability of Commercial Banks in Kenya". Economics and Finance Review, 1(15): 1-3.

[23]. Prasuna D G (2003).Performance Snapshot 2003-04. Chartered Financial Analyst, Vol. 10, No.11, pp.6-13.

[24]. Said, M (2003). Liquidity, solvency, and efficiency: An empirical analysis of the Japanese banks' distress. Journal of Oxford, Vol. 5, No.3, pp. 354-358.

[25]. Sangmi, Mohi-ud-Din (2010): “Analyzing Financial Performance of Commercial Banks in India; Application of CAMEL Model”. Pak. J. Commer. Soc. Sci 4(1): $40-55$.

APPENDIX 1

Table: Showing The Data For Roa And Camel

\begin{tabular}{|l|l|l|l|l|l|l|}
\hline Years & ROA & C & A & M & E & L \\
\hline 2001 & 4.82 & 0.458 & 16.9 & 16.9 & 27.37 & 52.9 \\
\hline 2002 & 2.63 & 0.525 & 21.27 & 21.27 & 27.55 & 52.5 \\
\hline 2003 & 2 & 0.444 & 21.27 & 21.27 & 20.32 & 50.9 \\
\hline 2004 & 2.58 & 0.136 & 21.59 & 21.59 & 18.22 & 52 \\
\hline 2005 & 0.75 & 0.212 & 20.13 & 20.13 & 4.07 & 50.2 \\
\hline 2006 & 0.59 & 0.346 & 7.92 & 7.92 & 3.47 & 55.7 \\
\hline 2007 & 5.92 & 0.324 & 8.3 & 8.3 & 20.58 & 48.8 \\
\hline 2008 & 4.29 & 0.33 & 6.25 & 6.25 & 18.27 & 44.3 \\
\hline 2009 & -64.72 & 0.327 & 32.8 & 32.8 & 22.87 & 30.7 \\
\hline 2010 & -18.17 & 0.329 & 19.5 & 19.5 & 20.57 & 37.5 \\
\hline
\end{tabular}

APPENDIX 2

Model Results

Descriptive Statistics

\begin{tabular}{|l|r|r|r|}
\hline & \multicolumn{1}{|c|}{ Mean } & Std. Deviation & N \\
\hline ROA & -5.93 & 21.762 & 10 \\
C & .34 & .114 & 10 \\
A & 17.59 & 8.120 & 10 \\
M & 17.59 & 8.120 & 10 \\
E & 18.33 & 8.337 & 10 \\
L & 47.55 & 7.850 & 10 \\
\hline
\end{tabular}




\section{Orrelations}

\begin{tabular}{|c|c|c|c|c|c|c|c|}
\hline & & ROA & $\mathrm{C}$ & A & $\mathrm{M}$ & $E$ & $\mathrm{~L}$ \\
\hline \multirow[t]{6}{*}{ Pearson Correlation } & ROA & 1.000 & .077 & -.693 & -.693 & -.165 & .865 \\
\hline & $\mathrm{C}$ & .077 & 1.000 & -.021 & -.021 & .539 & .129 \\
\hline & A & -.693 & -.021 & 1.000 & 1.000 & .320 & -.484 \\
\hline & $\mathrm{M}$ & -.693 & -.021 & 1.000 & 1.000 & .320 & -.484 \\
\hline & $E$ & -.165 & .539 & 320 & 320 & 1.000 & -.263 \\
\hline & $\mathrm{L}$ & .865 & .129 & -.484 & -.484 & -.263 & 1.000 \\
\hline \multirow[t]{6}{*}{ Sig. (1-tailed) } & ROA & & .416 & .013 & .013 & .324 & .001 \\
\hline & $\mathrm{C}$ & .416 & & .477 & .477 & .054 & .362 \\
\hline & A & .013 & .477 & & .000 & .183 & .078 \\
\hline & $\mathrm{M}$ & .013 & .477 & .000 & & .183 & .078 \\
\hline & $E$ & .324 & .054 & .183 & .183 & & .232 \\
\hline & $\mathrm{L}$ & .001 & .362 & .078 & .078 & .232 & \\
\hline \multirow[t]{6}{*}{$\mathrm{N}$} & ROA & 10 & 10 & 10 & 10 & 10 & 10 \\
\hline & C & 10 & 10 & 10 & 10 & 10 & 10 \\
\hline & A & 10 & 10 & 10 & 10 & 10 & 10 \\
\hline & $\mathrm{M}$ & 10 & 10 & 10 & 10 & 10 & 10 \\
\hline & $E$ & 10 & 10 & 10 & 10 & 10 & 10 \\
\hline & $\mathrm{L}$ & 10 & 10 & 10 & 10 & 10 & 10 \\
\hline
\end{tabular}

Model Summary ${ }^{b}$

\begin{tabular}{|c|c|c|c|c|c|c|c|c|c|c|}
\hline \multirow[b]{2}{*}{ Model } & \multirow[b]{2}{*}{$\mathrm{R}$} & \multirow[b]{2}{*}{ R Square } & \multirow[b]{2}{*}{$\begin{array}{l}\text { Adjusted R } \\
\text { Square } \\
\end{array}$} & \multirow[b]{2}{*}{$\begin{array}{l}\text { Std. Error of } \\
\text { the Estimate }\end{array}$} & \multicolumn{5}{|c|}{ Change Statistics } & \multirow[b]{2}{*}{$\begin{array}{l}\text { Durbin- } \\
\text { Watson }\end{array}$} \\
\hline & & & & & $\begin{array}{l}\text { R Square } \\
\text { Change }\end{array}$ & $\begin{array}{c}F \\
\text { Change }\end{array}$ & df1 & df 2 & $\begin{array}{c}\text { Sig. } F \\
\text { Change }\end{array}$ & \\
\hline 1 & $.940^{2}$ & .884 & .790 & 9.963 & .884 & 9.484 & 4 & 5 & .015 & 2.839 \\
\hline
\end{tabular}

a. Predictors: (Constant), L, C, A, M, E

b. b. Dependent Variable: ROA

ANOVA $^{b}$

\begin{tabular}{|l|l|r|r|r|r|r|}
\hline \multicolumn{1}{|l|}{ Model } & Sum of Squares & Df & Mean Square & \multicolumn{1}{c|}{ F } & \multicolumn{1}{c|}{ Sig. } \\
\hline 1 & Regression & 3765.888 & 4 & 941.472 & 9.484 & .015 \\
& Residual & 496.339 & 5 & 99.268 & & \\
& Total & 4262.226 & 9 & & & \\
\hline
\end{tabular}

a. Predictors: (Constant), L, C, M, E

b. Dependent Variable: ROA

\begin{tabular}{|c|c|c|c|c|c|c|}
\hline \multicolumn{7}{|c|}{ Coefficients $^{\mathrm{a}}$} \\
\hline & & \multicolumn{2}{|c|}{ Unstandardized Coefficients } & \multirow{2}{*}{$\frac{\text { Standardized Coefficients }}{\text { Beta }}$} & \multirow[b]{2}{*}{$\mathrm{t}$} & \multirow[b]{2}{*}{ Sig. } \\
\hline \multicolumn{2}{|c|}{ Model } & $\mathrm{B}$ & Std. Error & & & \\
\hline \multirow[t]{6}{*}{1} & (Constant) & -87.090 & 29.487 & & -2.953 & .032 \\
\hline & C & -31.434 & 36.810 & -.165 & -.854 & .432 \\
\hline & $\mathrm{A}$ & -1.108 & .483 & -.413 & -2.293 & .070 \\
\hline & $\mathrm{M}$ & -1.214 & .492 & -.413 & -2.174 & .0085 \\
\hline & E & .663 & .532 & .254 & 1.247 & .268 \\
\hline & $\mathrm{L}$ & 2.088 & .505 & .753 & 4.135 & .009 \\
\hline \multicolumn{3}{|c|}{ a. Dependent Variable: ROA } & & & & \\
\hline
\end{tabular}

